\section{PILOT RANDOMIZED STUDY ON THE RISK OF INTRAVENTRICULAR HEMORRHAGE WITH MIDLINE VERSUS LATERAL HEAD POSITIONS}

\author{
S. Al-Abdi', D.M. Nojoom², H. Alshaalan², \\ M. Al-Aamri ${ }^{1}$ \\ ${ }^{1}$ Pediatrics, King Abdulaziz Hospital (KAH), \\ Al-Ahsa, ${ }^{2}$ Medical Imaging Department, King \\ Abdulaziz Medical City, Riyadh, Saudi Arabia
}

Objective: To study a hypothesis that keeping preterm infants' heads in midline positions reduces their risk of intraventricular hemorrhage (IVH).

Methods: We conducted a pilot randomized trial to study this hypothesis by comparing the IVH risk associated with flat midline (FM) and flat lateral (FL) head positions throughout the first seven days of life. Randomization was stratified based on gender and gestational age ( $<27$ or 27-29.9 weeks).

Results: Twenty-three infants younger than 30 weeks gestation were randomly assigned to the FM group, and 21 infants of similar age were assigned to the FL group (right-tilted: $n=9$; left-tilted: $n=12$ ). Important baseline characteristics were similar in both groups, except for multiple births which were significantly higher in the FM group. The risk of IVH was higher in the FM group than in the FL group (6 vs. 4 ; risk ratio (RR) $1.4 ; 95 \%$ confidence interval $(\mathrm{Cl})$ : 0.4-4.2; $\mathrm{p}=0.8)$. A secondary analysis showed that the risk of IVH was two times higher in the FM group than in the right-tilted FL group (6 vs. 1; RR 2.3; 95\% Cl: 0.3-16.9; $p=0.6$ ) and was the same in the FM and left-tilted FL groups (6 vs. 3; RR 1.0; $95 \% \mathrm{Cl}: 0.3-3.5 ; p>0.99$ ).

Conclusions: Keeping a preterm infant's head in the FM position throughout the first seven days of life does not decrease the risk of IVH; however, a right-tilted FL position may reduce this risk. A larger study is needed for a definitive conclusion.

\section{6}

\section{RADIOGRAPHIC EXPOSURE IN THE FIRST WEEKS OF LIFE IN PRETERM INFANTS}

\author{
S. Sanka, A. Curley
}

Neonatal Intensive Care Unit, Addenbrookes Hospital NHS Trust, Cambridge, UK

Aim: To determine the number of $x$ rays performed on preterm infants ( $<30$ weeks gestation) admitted to a tertiary centre during the first seven weeks of life.
Methods: We calculated the number of chest, abdominal (AP and lateral), combined chest/ abdominal $\mathrm{x}$ rays and $\mathrm{x}$ rays taken for contrast studies during the first seven weeks of life in preterm infants under 30 weeks gestation admitted to a single tertiary centre during 2008 .

\section{Results:}

\begin{tabular}{|l|l|l|l|l|l|}
\hline $\begin{array}{l}\text { Jan- } \\
\text { Dec } \\
2008\end{array}$ & $\begin{array}{l}\text { CXR } \\
\text { Median } \\
\text { (range) }\end{array}$ & $\begin{array}{l}\text { AXR } \\
\text { Median } \\
\text { (range) }\end{array}$ & $\begin{array}{l}\text { CAXR } \\
\text { Median } \\
\text { (range) }\end{array}$ & $\begin{array}{l}\text { Contrast } \\
\text { study } \\
\text { images. } \\
\text { Pt= } \\
\text { patient }\end{array}$ & $\begin{array}{l}\text { No. of } \\
\text { babies } \\
\text { (No. of } \\
\text { weeks } \\
\text { stay) }\end{array}$ \\
\hline $24 \mathrm{~W}$ & $\begin{array}{l}8(1- \\
22)\end{array}$ & $1(0-3)$ & $\begin{array}{l}3(0- \\
10)\end{array}$ & none & $11(50)$ \\
\hline $25 \mathrm{~W}$ & $\begin{array}{l}3.5(0- \\
13)\end{array}$ & $\begin{array}{l}0.5(0- \\
9)\end{array}$ & $4(0-11)$ & $24(1 \mathrm{pt})$ & $14(70)$ \\
\hline $26 \mathrm{~W}$ & $\begin{array}{l}3(1- \\
18)\end{array}$ & $0(0-9)$ & $\begin{array}{l}3.5(1- \\
7)\end{array}$ & 0 & $12(46)$ \\
\hline $27 \mathrm{~W}$ & $\begin{array}{l}2(1- \\
14)\end{array}$ & $1(0-5)$ & $\begin{array}{l}2(0- \\
13)\end{array}$ & 0 & $25(88)$ \\
\hline $28 \mathrm{~W}$ & $2(0-8)$ & $0(0-6)$ & $2(0-11)$ & $8(1 \mathrm{pt})$ & $23(78)$ \\
\hline $29 \mathrm{~W}$ & $\begin{array}{l}2(0- \\
12)\end{array}$ & $0(0-7)$ & $\begin{array}{l}2(0- \\
10)\end{array}$ & $9(1 \mathrm{pt})$ & $21(71)$ \\
\hline $30 \mathrm{~W}$ & $\begin{array}{l}1(0- \\
16)\end{array}$ & $0(0-1)$ & $0(0-4)$ & 0 & $15(58)$ \\
\hline
\end{tabular}

[Results]

Conclusions: Preterm infants are exposed to a number of radiographs in the early weeks of life due to associated morbidities and also have diagnostic procedures that may involve $X$ ray radiation. Repeated handling for radiographs can cause clinical instability and accumulation of a radiation dose that can have serious health consequences. Careful consideration should be given before requesting a radiograph in this vulnerable group.

\section{7}

\section{THE EFFECTS OF A DESIGNED PROGRAM ON OXYGEN SATURATION AND HEART RATE OF PREMATURE INFANTS HOSPITALIZED IN NICU IN -2009}

\author{
P. Taheri, E. Abbasi, Z. Abdeyazdan, \\ N. Fathizadeh
}

\section{Paediatric Nursing Dept, University Hospital Paediatric, Isfahan, Iran}

Background: Prematurity is the main cause of death in infants under one years of age and is the main reason for NICU hospitalization. The stressful environment of NICU exposes preterm infants to 